\title{
Antimicrobial Activity of Some Lactic Acid Bacteria Isolated From Human Milk
}

\author{
Nayara Alves Reis (I), Norma Suely Evangelista-Barreto (I), \\ Margarete Alice Fontes Saraiva (II), Elaine Araújo de Carvalho (I), \\ Adriana Pereira Sampaio (I), Alessandra Santana Silva (I) \\ (I) UFRB - UNIVERSIDADE FEDERAL DO RECÔNCAVO DA BAHIA (Rua Rui Barbosa, 710, \\ Centro Cruz das Almas-BAHIA-BRASIL, CEP:44.380-000), (II) UFOP - UNIVERSIDADE \\ FEDERAL DE OURO PRETO (Rua Diogo de Vasconcelos, 328 - Pilar, Ouro Preto - MG - \\ BRASIL - 35400-000)
}

\section{Resumo}

Healthy eating reflects the interest in functional foods, or foods that are able to perform beneficial physiological effects for the prevention of diseases and the increase in life expectancy. Accordingly, consumers are increasingly interested in the probiotic foods. Probiotic are live microorganisms administered in adequate amounts that confer a beneficial health effect on the host. Breast milk, besides being very nutritious and essential for the development of the neonatal gut microflora, it contains potentially probiotic lactic acid bacteria. The ability to compete with other micro-organisms in the intestinal tract is important feature for the selection of micro-organisms candidate probiotic. The aim of the present study was planned to verify the antibacterial activity of lactic acid bacteria isolated from human milk. The antimicrobial activity of lactic acid bacteria were against six indicator strains, Escherichia coli, Enterococcus faecalis, Listeria inoccua, Listeria monocytogenes, Staphylococcus aureus and Salmonella Enteretidis by using the spot-on-lawn method. All isolates from human milk showed a good antimicrobial activity against the tested indicator strains with differences in size of inhibition zone $(\mathrm{mm})$. The size of inhibition zone was between $13.12 \mathrm{~mm}$ and $20.83 \mathrm{~mm}$ in diameter against Enterococcus faecalis, $20.00 \mathrm{~mm}$ and $36.88 \mathrm{~mm}$ against Salmonella Enteretidis, $13.75 \mathrm{~mm}$ and $27.9 \mathrm{~mm}$ against Listeria monocytogenes, 13.47 
$\mathrm{mm}$ and $22.37 \mathrm{~mm}$ against Staphylococcus aureus, $16.81 \mathrm{~mm}$ and 26.69 $\mathrm{mm}$ against Listeria inoccua, and $11.72 \mathrm{~mm}$ and $21.51 \mathrm{~mm}$ against Escherichia coli. The inhibitory activity observed is due to the production of antimicrobial substances that have been spread by agar and prevented the growth of micro-organisms indicators. Lactic acid bacteria produce a number of antimicrobial metabolic end products such as organic acids, bacteriocin, diacetyl and hydrogen peroxide. Further studies will be conducted to characterize the nature of antagonistic substances produced by these isolates. These results obtained revealed the possibility of using lactic acid bacteria isolated from human milk as probiotic, because it can reduce the risk of infectious diseases.

Palavras-Chave: health, intestinal flora, probiotic

Agência de Fomento: CAPES (Coordenação de Aperfeiçoamento de Pessoal de Nível Superior) 